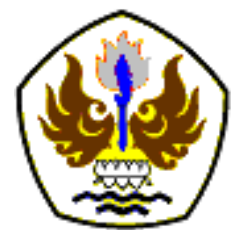

INFOMATEK

Volume 20 Nomor 2 Desember 2018

\title{
PENGARUH ANTHROPOMETRI DAN LINGKUNGAN FISIK KERJA PADA KECEPATAN WAKTU PERAKITAN OTOPED
}

\author{
Hermita Dyah Puspita*, Anis Septiani
}

Jurusan Teknik Industri

Fakultas Teknik - Universitas Jenderal Achmad Yani

\begin{abstract}
Abstrak: Keberhasilan kerja manusia dipengaruhi oleh dua faktor, yaitu : faktor individual dan faktor situasional. Faktor individual adalah faktor yang sudah melekat dan sudah ada pada diri masing-masing pekerja dimana hal ini tidak bisa diubah, salah satu contohnya adalah ukuran anthropometri individu pekerja. Sedangkan faktor situasional justru merupakan faktor yang dapat diubah dan dapat diatur. Faktor lingkungan dimana individu bekerja merupakan faktor situasional, seperti: temperatur, kelembaban, sirkulasi udara, kebisingan, getaran mekanik, warna, bau-bauan dan pencahayaan. Lingkungan kerja dikatakan baik jika pekerja dapat melakukan pekerjaan secara optimal, sehat dan aman. Ketidaksesuaian lingkungan kerja dapat mempengaruhi performansi pekerja dalam bekerja dimana dalam jangka panjang hal tersebut akan menyebabkan penurunan produktifitas kerja. Oleh karena itu lingkungan kerja harus dibuat dan atau dirancang sedemikian rupa sehingga menjadi kondusif bagi pekerja untuk melakukan pekerjaannya dengan nyaman dan aman. Dari penelitian ini didapatkan ukuran anthropometri yang ideal untuk pekerja perakitan otoped yang menghasilkan performansi kerja yang optimal adalah persentile ke-80 dan juga diketahui temperatur $20^{\circ} \mathrm{C}-30^{\circ} \mathrm{C}$ masih merupakan temperatur yang nyaman buat pekerja perakitan otoped, kebisingan $50 \mathrm{~dB}-85 \mathrm{~dB}$ juga masih merupakan kebisingan yang nyaman buat pekerja perakitan otoped dan pencahayaan yang nyaman bagi pekerja perakitan otoped yang dapat menghasilkan produktifitas kerja yang baik adalah pada 150 lux.
\end{abstract}

Kata Kunci : Pengaruh, Anthropometri, Faktor Lingkungan Fisik Kerja

\section{PENDAHULUAN}

Keberhasilan kerja manusia dipengaruhi oleh dua faktor, yaitu : faktor individual dan faktor situasional. Faktor individual adalah faktor yang sudah melekat dan sudah ada pada diri masing-masing pekerja dimana hal ini tidak bisa diubah, salah satu contohnya adalah

\footnotetext{
*) hermita.dp@lecture.unjani.ac.id

Pertama diterima : 19 Oktober 2018

Direvisi : 21 Okober 2018

Disetujui untuk publikasi: 10 November 2018
}

anthropometri individu. Sedangkan faktor situasional justru merupakan faktor yang dapat diubah dan dapat diatur. Faktor lingkungan dimana individu bekerja merupakan faktor situasional, seperti: kebisingan, pencahayaan, temperatur, kelembaban, sirkulasi udara, getaran mekanik, warna dan bau-bauan.

Lingkungan kerja dikatakan baik jika pekerja dapat melakukan pekerjaan secara optimal, sehat dan aman. Ketidaksesuaian lingkungan 
kerja dapat mempengaruhi performansi pekerja dalam bekerja dimana dalam jangka panjang hal tersebut akan menyebabkan penurunan produktifitas kerja. Oleh karena itu lingkungan kerja harus dibuat dan atau dirancang sedemikian rupa sehingga menjadi kondusif bagi pekerja untuk melakukan pekerjaannya dengan nyaman dan aman (Sutalaksana dkk, 2006 [1]).

Kebisingan adalah salah satu unsur lingkungan kerja yang memiliki peran penting dalam mempengaruhi produktivitas pekerja. Terlalu bising dapat menyebabkan pekerja kurang berkonsentrasi pada tugasnya. Bekerja di lingkungan kerja yang redup atau sangat terang sekali dapat membuat mata cepat mengalami kelelahan, sakit kepala dan mudah tersinggung. Sumber pencahayaan seperti sinar matahari yang dapat menghasilkan bayangan dan kesilauan yang tidak diinginkan di tempat kerja dapat mengganggu terutama pada kinerja tugas visual. Sedangkan tingkat pencahayaan rendah dapat menyebabkan depresi bagi sebagian orang. Sistem pencahayaan yang buruk dapat mengurangi kinerja pekerja serta produktivitasnya. Pekerja yang bekerja di bagian perakitan memerlukan cahaya yang sesuai dan pas. Cahaya yang berlebihan dapat menyebabkan kesulitan melihat part-part pada saat merakit. Selain itu, pekerja yang bekerja pada kualitas pencahayaan yang lebih baik cenderung menghasilkan kerja yang lebih cepat dan lebih sedikit kesalahannya dibandingkan dengan pekerja yang bekerja pada kualitas pencahayaan yang kurang.

Unsur terakhir dari lingkungan kerja yang dibahas dalam penelitian ini adalah temperatur, yang juga memiliki dampak pada produktivitas pekerja. Kelesuan dan kelelahan karyawan akibat peningkatan suhu tubuh dapat menyebabkan penurunan efisiensi. Tingkat suhu rendah menurunkan efisiensi akibat panas tubuh lebih dingin dan akibatnya tubuh akan menggigil. Sebaliknya jika tingkat suhu tinggi akan menyebabkan penguapan keringat tubuh terhambat. Kelembaban rendah memiliki efek kurang bagus pada kemampuan untuk bernafas dan menelan. Kelembaban rendah dapat menyebabkan rasa tidak nyaman seperti mulut dan hidung menjadi kering karena meningkatnya tingkat penguapan.

Akbari et.al 2013 [2] menguji hubungan antara pencahayaan dan tingkat kebisingan pada produktivitas pekerja di bidang industri perakitan otomotif. Hasil dari pengujian tersebut didapatkan bahwa faktor kebisingan berpengaruh secara signifikan terhadap produktivitas kerja tetapi tidak demikian dengan pencahayaan. Akbari merekomendasikan bahwa tingkat kebisingan yang masih nyaman dan yang dapat 
meningkatkan produktifitas bagi pekerja di tempat kerja adalah kurang dari $85 \mathrm{~dB}$.

Menurut Vimalanathan dan Ramesh Babu 2014 [3] temperatur dan pencahayaan secara signifikan berpengaruh terhadap kinerja pekerja kantor. Dalam penelitiannya dijelaskan bahwa temperatur dalam ruangan memiliki efek pengaruh yang lebih signifikan dibandingkan efek pencahayaan baik secara independen ataupun secara gabungan. Hasil dari penelitian Vimalanathan dan Ramesh Babu didapatkan temperatur dan pencahayaan optimal yang dapat meningkatkan kesehatan dan kinerja pekerja kantor yaitu pada temperatur $21^{\circ} \mathrm{C}$ dan pencahayaan 1000 lux.

Seppänen et.al 2006 [4] menyatakan suhu ruangan mempengaruhi beberapa respons manusia, termasuk thermal kenyamanan, kualitas udara yang dirasakan, gejala sindrom ruang sempit dan kinerja di tempat kerja. Dalam penelitiannya, difokuskan pada efek suhu pada kinerja pada pekerjaan kantor, seperti pengolahan teks, perhitungan sederhana (penambahan, perkalian), lama waktu layanan pelanggan telepon, dan total waktu penanganan per pelanggan untuk pekerja call center. Hasilnya menunjukkan bahwa kinerja meningkat dengan suhu hingga

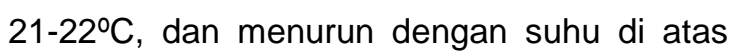
23-24ํㅡ. Produktivitas tertinggi pada suhu sekitar $22^{\circ}$ C. Pada suhu $30^{\circ} \mathrm{C}$ kinerja hanya $91,1 \%$

Dari beberapa literatur survei penelitian yang sudah disebutkan diatas, faktor Anthropometri tidak disertakan dalam penelitian-penelitian tersebut. Anthropometri merupakan bagian dari ilmu ergonomi yang berhubungan dengan dimensi tubuh manusia yang meliputi bentuk, ukuran, kekuatan dan penerapannya untuk kebutuhan perancangan fasilitas aktivitas manusia. Data anthropometri sangat diperlukan untuk perancangan peralatan dan lingkungan kerja. Kenyamanan penggunaan alat tergantung pada kesesuaian ukuran alat dengan ukuran manusia. Jika tidak sesuai dalam jangka waktu tertentu akan mengakibatkan stress tubuh berupa : lelah, nyeri dan pusing.

Pada penelitian-penelitian yang telah dilakukan di bidang ergonomi dan lingkungan kerja kebanyakan responnya menggunakan respon time dan performansi kerja responden diukur pada saat responden melakukan pekerjaan administrasi di kantor. Belum ada penelitian ergonomi yang membahas tentang pengaruh dari ketiga faktor lingkungan secara bersama-sama, yaitu : temperatur, kebisingan dan pencahayaan ditambah dengan faktor anthropometri, dimana performansi kerja diukur pada pekerja yang merakit otoped. 


\section{METODOLOGI}

Tahap ini menjelaskan langkah-langkah penelitian secara sistematis dalam rangka mencapai tujuan penelitian. Tahapan yang dilalui dapat dilihat pada Gambar 1.

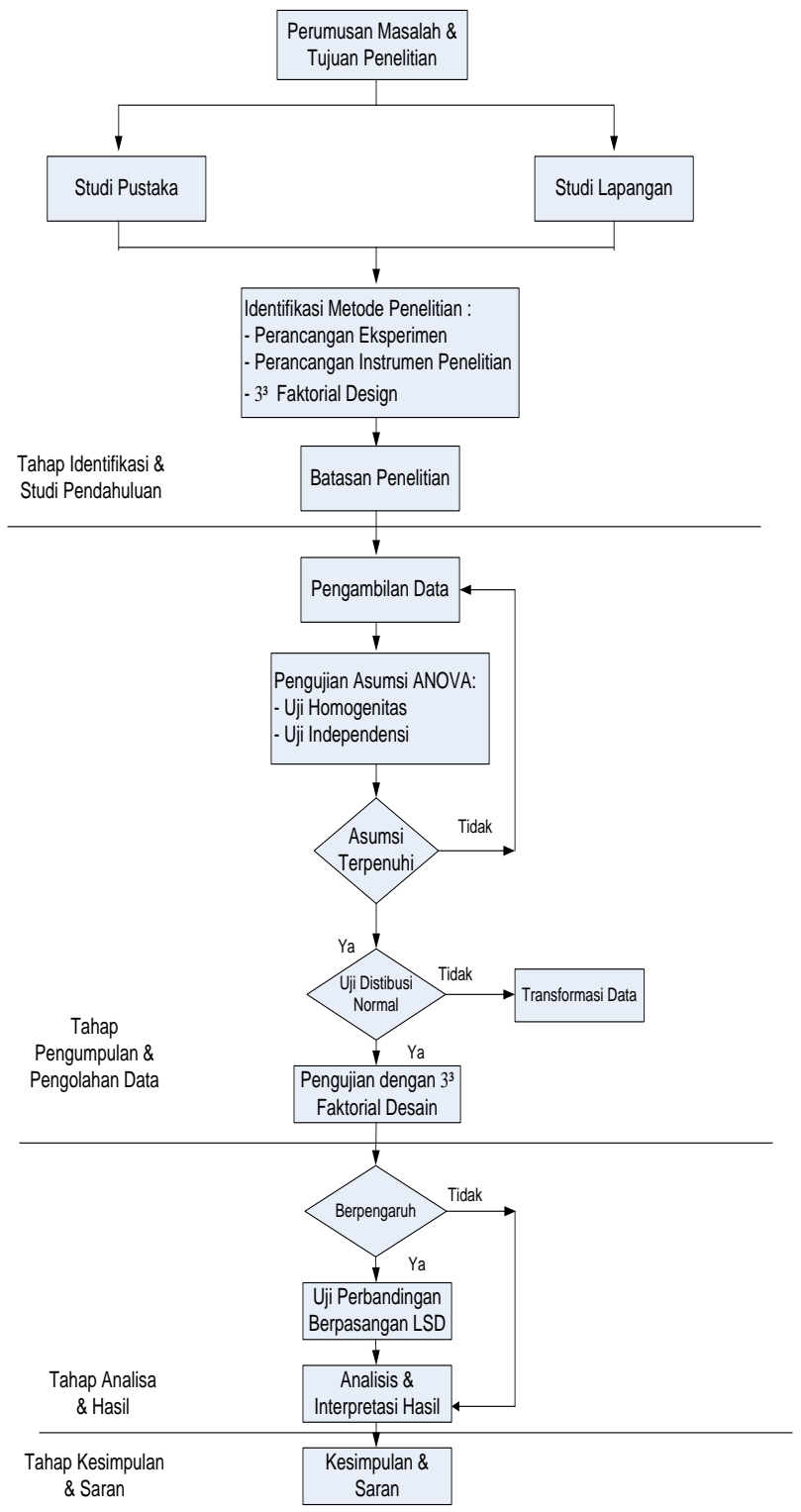

Gambar 1.

Flow Chart Metodologi Penelitian
Tabel 1

Karakteristik Peneltian

\begin{tabular}{|c|c|}
\hline Karakteristik & Keterangan \\
\hline $\begin{array}{c}\text { Unit } \\
\text { Eksperimen }\end{array}$ & Operator / Responden \\
\hline \multirow{4}{*}{ Faktor } & Suhu \\
\hline & Kebisingan \\
\hline & Penerangan \\
\hline & Persentile \\
\hline \multirow{18}{*}{ Level } & Suhu $1\left(20^{\circ} \mathrm{C}\right)$ \\
\hline & Suhu $2\left(24^{\circ} \mathrm{C}\right)$ \\
\hline & Suhu $3\left(30^{\circ} \mathrm{C}\right)$ \\
\hline & Kebisingan 1 (50db) \\
\hline & Kebisingan 2 (60db) \\
\hline & Kebisingan 3 (85db) \\
\hline & Penerangan 1 (150 Lux) \\
\hline & Penerangan 2 (300 Lux) \\
\hline & Penerangan 3 (400 Lux) \\
\hline & Persentile 20 \\
\hline & Persentile 35 \\
\hline & Persentile 45 \\
\hline & Persentile 75 \\
\hline & Persentile 77.5 \\
\hline & Persentile 80 \\
\hline & Persentile 85 \\
\hline & Persentile 90 \\
\hline & Persentile 97.5 \\
\hline $\begin{array}{l}\text { Variabel } \\
\text { Respon }\end{array}$ & $\begin{array}{l}\text { Waktu Kerja Operator menyelesaikan } \\
\text { perakitan otoped }\end{array}$ \\
\hline \multirow{4}{*}{ Alat Ukur } & $\begin{array}{l}\text { Sound Level Meter (untuk mengukur tingkat } \\
\text { kebisingan) }\end{array}$ \\
\hline & AC (untuk mengukur tingkat suhu) \\
\hline & $\begin{array}{l}\text { Lux Meter (untuk mengukur tingkat } \\
\text { penerangan) }\end{array}$ \\
\hline & $\begin{array}{l}\text { Stopwatch (untuk mengukur waktu } \\
\text { perakitan) }\end{array}$ \\
\hline Replikasi & 1 kali untuk masing-masing responden \\
\hline $\begin{array}{c}\text { Metode } \\
\text { Eksperimen }\end{array}$ & $\begin{array}{l}\text { Analisa Faktorial } 3^{\wedge} 3 \rightarrow \text { jumlah data } 270 \\
\text { data }\end{array}$ \\
\hline
\end{tabular}

\section{ANALISIS DAN PEMBAHASAN}

\subsection{Pengujian Asumsi}

Sebelum dilakukan uji Analisa Faktorial, maka data perlu dilakukan dulu uji asumsi. Uji asumsi yang harus dipenuhi adalah uji distribusi normal (Tabel 2), uji independensi 
(Tabel 3) dan uji homogenitas varians (Tabel 4).

\section{A.Uji Distribusi Normal}

$\mathrm{H}_{0}$ : Data berdistribusi Normal

$\mathrm{H}_{1}$ : Data Tidak berdistribusi Normal

Dari uji Kolmogorov smirnov untuk variabel waktu perakitan didapatkan bahwa signifikansi-nya sebesar 0,202 yang lebih besar dari alpha (5\%), sehingga keputusannya adalah terima Ho. Artinya bahwa data waktu perakitan berdistribusi normal.

Tabel 2

Uji Kolmogorov-Smirnov

\begin{tabular}{ccc}
\hline & & $\begin{array}{c}\text { Waktu } \\
\text { Perakitan }\end{array}$ \\
\hline Normal & $\mathrm{N}$ & 270 \\
Parameters, & Mean & 1.9692 \\
Most Extreme & Std. Deviation & 0.96989 \\
Differences & Absolute & .151 \\
& Positive & .151 \\
Kolmogorov-Smirnov Z & -.092 \\
& Negative & 1.070 \\
\hline \multicolumn{2}{c}{ Asymp. Sig. (2-tailed) } & .202 \\
\hline
\end{tabular}

\section{B.Uji Independensi}

$\mathrm{H}_{0}$ : Data antar variabel independen

$\mathrm{H}_{1}$ : Data antar variabel tidak independent

Dari uji Chi Square di atas untuk uji independensi didapatkan bahwa masingmasing asymp. signifikansi-nya sebesar 1.000 yang lebih besar dari alpha (5\%), sehingga keputusannya adalah terima Ho. Artinya bahwa antara faktor-faktor saling independen, suhu, lighting, noise dan anthropometri, semua saling independen.
Tabel 3.

Uji Independensi

\begin{tabular}{|c|c|c|c|c|}
\hline & Suhu & Lighting & Noise & Anthropometri \\
\hline Chi-Square & $.000^{\mathrm{a}}$ & $.000^{a}$ & $.000^{\mathrm{a}}$ & $.000^{\mathrm{b}}$ \\
\hline $\mathrm{df}$ & 2 & 2 & 2 & 8 \\
\hline Asymp. Sig. & 1.000 & 1.000 & 1.000 & 1.000 \\
\hline \multicolumn{5}{|c|}{$\begin{array}{l}\text { a. } 0 \text { cells }(0.0 \%) \text { have expected frequencies less than } 5 \text {. The } \\
\text { minimum expected cell frequency is } 90.0 \text {. } \\
\text { b. } 0 \text { cells }(0.0 \%) \text { have expected frequencies less than } 5 \text {. The } \\
\text { minimum expected cell frequency is } 135.0 \text {. }\end{array}$} \\
\hline
\end{tabular}

\section{C.Uji Homogenitas Varians}

Uji homogenitas dimaksudkan untuk memperlihatkan bahwa dua atau lebih Kelompok data sampel berasal dari populasi yang memiliki variansi yang sama. Hipotesis untuk uji homogenitas adalah:

$\mathrm{H}_{\mathrm{o}}$ : Variansi pada tiap kelompok sama (homogen)

$\mathrm{H}_{1}$ : Variansi pada tiap kelompok tidak sama (tidak homogen)

Hasil perhitungan uji homogenitas varians dengan Levene Statistics di atas menunjukkan nilai signifikansi sebesar 0.870 untuk variable waktu perakitan. Uji homogenitas varians adalah pengujian terhadap asumsi dalam uji ANOVA, yaitu varians harus homogen. Karena nilai signifikansi yang diperoleh lebih besar dari dari $\alpha=5 \%$, maka terima Ho. Artinya varians dari waktu perakitan adalah sama,begitu juga varians dari kelompok waktu perakitan adalah sama. 
Tabel 4.

Test of Homogeneity of Variances Waktu

\begin{tabular}{|c|c|c|c|}
\hline $\begin{array}{l}\text { Levene } \\
\text { Statistic }\end{array}$ & $\mathrm{df1}$ & $\mathrm{df2}$ & \\
\hline .140 & 2 & 267 & Sig. \\
\hline
\end{tabular}

\subsection{Analisa Faktorial}

Rancangan faktorial bertujuan dan digunakan untuk mempelajari interaksi dari faktor yang dicobakan dalam mewujudkan suatu gejala atau respon dalam suatu peristiwa baik pengaruh utama maupun interaksi secara simultan dari faktor tersebut. Adanya interaksi ini merupakan kelebihan sekaligus sebagai ciri dari percobaan faktorial dibanding percobaan satu faktor karena dimungkinkannya mengetahui pengaruh interaksi dari faktorfaktor yang dicobakan. Interaksi adalah tanggap differensial (differensial response) terhadap sebuah kombinasi faktor dengan berbagai taraf faktor kedua dan faktor ketiga yang dilakukan secara seksama.

Hipotesis untuk uji analisa faktorial adalah :

$\mathrm{H}_{\mathrm{o}}$ : Faktor tidak berpengaruh terhadap penyelesaian waktu perakitan

$\mathrm{H}_{1}$ : Faktor berpengaruh terhadap penyelesaian waktu perakitan

Dari perhitungan Analisa Faktorial yang telah dilakukan dengan bantuan SPSS Versi 25 seperti pada Tabel 5 dan 6 , didapatkan hasil bahwa adanya beberapa faktor yang tidak saling berpengaruh dan ada beberapa faktor yang berpengaruh. Demikian juga dengan interaksi antara faktor-faktor ada yang berpengaruh dan ada yang tidak berpengaruh. Faktor dikatakan berpengaruh jika level signifikansi-nya lebih kecil dari a (5\%), sedangkan jika level signifikansi-nya lebih besar dari $\alpha$, artinya faktor tersebut tidak berpengaruh.

Pada penelitian ini faktor yang berpengaruh adalah faktor persentil dan faktor lighting (penerangan),sedangkan faktor suhu dan noise tidak berpengaruh. Sementara interaksi yang berpengaruh adalah interaksi antara persentil dan lighting dan juga interaksi antara persentil dan suhu. Di luar itu tidak ada interaksi-interaksi lain yang berpengaruh. Sedangkan untuk mengetahui persentile yang mana yang mempengaruhi waktu penyelesaian perakitan otoped dapat dilihat pada Tabel 7. Dari tabel berpasangan dapat disimpulkan bahwa persentile-80 merupakan persentile yang cocok untuk operator perakitan otoped dikarenakan ruang kerja perakitan yang relatif tidak luas tetapi hanya cukup untuk dua operator.Selain itu jangkauan tangan yang panjang dari operator persentil 80 mempermudah operator untuk melakukan proses perakitan untuk memegang rangka otoped yang memiliki dimensi panjang $50 \mathrm{~cm}$ lebih. 
Tabel 5

Tests of Between-Subjects Effects

Dependent Variable: Wkt Perakitan

\begin{tabular}{|c|c|c|c|c|c|}
\hline Source & $\begin{array}{l}\text { Type III } \\
\text { Sum of } \\
\text { Squares }\end{array}$ & $\mathrm{df}$ & $\begin{array}{l}\text { Mean } \\
\text { Square }\end{array}$ & $\mathrm{F}$ & Sig. \\
\hline Corrected Model & $243.190^{a}$ & 242 & 1.005 & 2.754 & .001 \\
\hline Intercept & 990.334 & 1 & 990.334 & $\begin{array}{r}2713 . \\
601\end{array}$ & .000 \\
\hline Persentile & 38.629 & 7 & 5.518 & $\begin{array}{r}15.12 \\
1\end{array}$ & .000 \\
\hline Suhu & .054 & 2 & .027 & .074 & .929 \\
\hline Lighting & 83.638 & 2 & 41.819 & $\begin{array}{r}114.5 \\
87\end{array}$ & .000 \\
\hline Noise & .701 & 2 & .350 & .960 & .395 \\
\hline $\begin{array}{l}\text { Persentile * } \\
\text { Suhu }\end{array}$ & 12.252 & 14 & .875 & 2.398 & .025 \\
\hline $\begin{array}{l}\text { Persentile * } \\
\text { Lighting }\end{array}$ & 43.116 & 14 & 3.080 & 8.439 & .000 \\
\hline $\begin{array}{l}\text { Persentile * } \\
\text { Noise }\end{array}$ & 1.466 & 14 & .105 & .287 & .991 \\
\hline Suhu * Lighting & 1.663 & 4 & .416 & 1.139 & .359 \\
\hline Suhu * Noise & .807 & 4 & .202 & .553 & .699 \\
\hline Lighting * Noise & 1.012 & 4 & .253 & .693 & .603 \\
\hline $\begin{array}{l}\text { Persentile * } \\
\text { Suhu * Lighting }\end{array}$ & 8.412 & 28 & .300 & .823 & .694 \\
\hline $\begin{array}{l}\text { Persentile * } \\
\text { Suhu * Noise }\end{array}$ & 3.656 & 28 & .131 & .358 & .996 \\
\hline $\begin{array}{l}\text { Persentile * } \\
\text { Lighting * Noise }\end{array}$ & 3.793 & 28 & .135 & .371 & .994 \\
\hline $\begin{array}{l}\text { Suhu * Lighting * } \\
\text { Noise }\end{array}$ & 1.162 & 8 & .145 & .398 & .912 \\
\hline Source & $\begin{array}{l}\text { Type III } \\
\text { Sum of } \\
\text { Squares }\end{array}$ & df & $\begin{array}{l}\text { Mean } \\
\text { Square }\end{array}$ & $F$ & Sig. \\
\hline $\begin{array}{l}\text { Persentile * } \\
\text { Suhu * Lighting * } \\
\text { Noise }\end{array}$ & 6.912 & 56 & .123 & .338 & 1.000 \\
\hline Error & 9.854 & 27 & .365 & & \\
\hline Total & $\begin{array}{r}1300.02 \\
0\end{array}$ & 270 & & & \\
\hline Corrected Total & 253.043 & 269 & & & \\
\hline
\end{tabular}

a. R Squared $=.961($ Adjusted $R$ Squared $=.612)$
Tabel 6

Hipotesa Penelitian dan Hasil Keputusan

\begin{tabular}{|c|c|c|c|c|}
\hline No & Hipotesa & Sig. & Keputusan & Kesimpulan \\
\hline \multirow[t]{2}{*}{1} & $\begin{array}{l}\mathrm{H}_{0} \text { : Tidak ada } \\
\text { pengaruh } \\
\text { Persentile } \\
\text { terhadap } \\
\text { penyelesaian } \\
\text { waktu perakitan }\end{array}$ & \multirow[t]{2}{*}{0,000} & \multirow[t]{2}{*}{ Tolak $\mathrm{H}_{\mathrm{o}}$} & \multirow{2}{*}{$\begin{array}{c}\text { Ada } \\
\text { pengaruh } \\
\text { Persentile }\end{array}$} \\
\hline & $\begin{array}{l}\mathrm{H}_{1} \text { : Ada pengaruh } \\
\text { Persentile } \\
\text { terhadap } \\
\text { penyelesaian } \\
\text { waktu perakitan }\end{array}$ & & & \\
\hline \multirow{2}{*}{2} & $\begin{array}{l}\mathrm{H}_{0}: \text { Tidak ada } \\
\text { pengaruh faktor } \\
\text { Lighting terhadap } \\
\text { penyelesaian } \\
\text { waktu perakitan }\end{array}$ & \multirow{2}{*}{0,000} & \multirow{2}{*}{ Tolak $\mathrm{H}_{\mathrm{o}}$} & \multirow{2}{*}{$\begin{array}{c}\text { Ada } \\
\text { pengaruh } \\
\text { Lighting }\end{array}$} \\
\hline & $\begin{array}{l}\mathrm{H}_{1} \text { : Ada pengaruh } \\
\text { faktor Lighting } \\
\text { terhadap } \\
\text { penyelesaian } \\
\text { waktu perakitan }\end{array}$ & & & \\
\hline \multirow[t]{2}{*}{3} & $\begin{array}{l}\mathrm{H}_{\mathrm{o}} \text { : Tidak ada } \\
\text { pengaruh interaksi } \\
\text { antara Persentile } \\
\text { dan faktor Suhu } \\
\text { terhadap } \\
\text { penyelesaian } \\
\text { waktu perakitan }\end{array}$ & 0,000 & Tolak Ho & $\begin{array}{c}\text { Ada } \\
\text { pengaruh } \\
\text { Interaksi } \\
\text { antara } \\
\text { Persentile \& } \\
\text { Suhu }\end{array}$ \\
\hline & $\begin{array}{l}\mathrm{H}_{1} \text { : Ada pengaruh } \\
\text { interaksi antara } \\
\text { Persentile dan } \\
\text { faktor Suhu } \\
\text { terhadap } \\
\text { penyelesaian } \\
\text { waktu perakitan }\end{array}$ & & & \\
\hline \multirow{2}{*}{4} & $\begin{array}{l}\mathrm{H}_{\mathrm{o}} \text { : Tidak ada } \\
\text { pengaruh interaksi } \\
\text { antara Persentile } \\
\text { dan faktor Lighting } \\
\text { terhadap } \\
\text { penyelesaian } \\
\text { waktu perakitan }\end{array}$ & \multirow{2}{*}{0.025} & \multirow{2}{*}{ Tolak $\mathrm{H}_{\mathrm{o}}$} & \multirow{2}{*}{$\begin{array}{c}\text { Ada } \\
\text { pengaruh } \\
\text { Interaksi } \\
\text { antara } \\
\text { Persentile \& } \\
\text { Lighting }\end{array}$} \\
\hline & $\begin{array}{l}\mathrm{H}_{1} \text { : Ada pengaruh } \\
\text { interaksi antara } \\
\text { Persentile dan } \\
\text { faktor Lighting } \\
\text { terhadap } \\
\text { penyelesaian } \\
\text { waktu perakitan }\end{array}$ & & & \\
\hline
\end{tabular}


Tabel 7

Multiple Comparisons

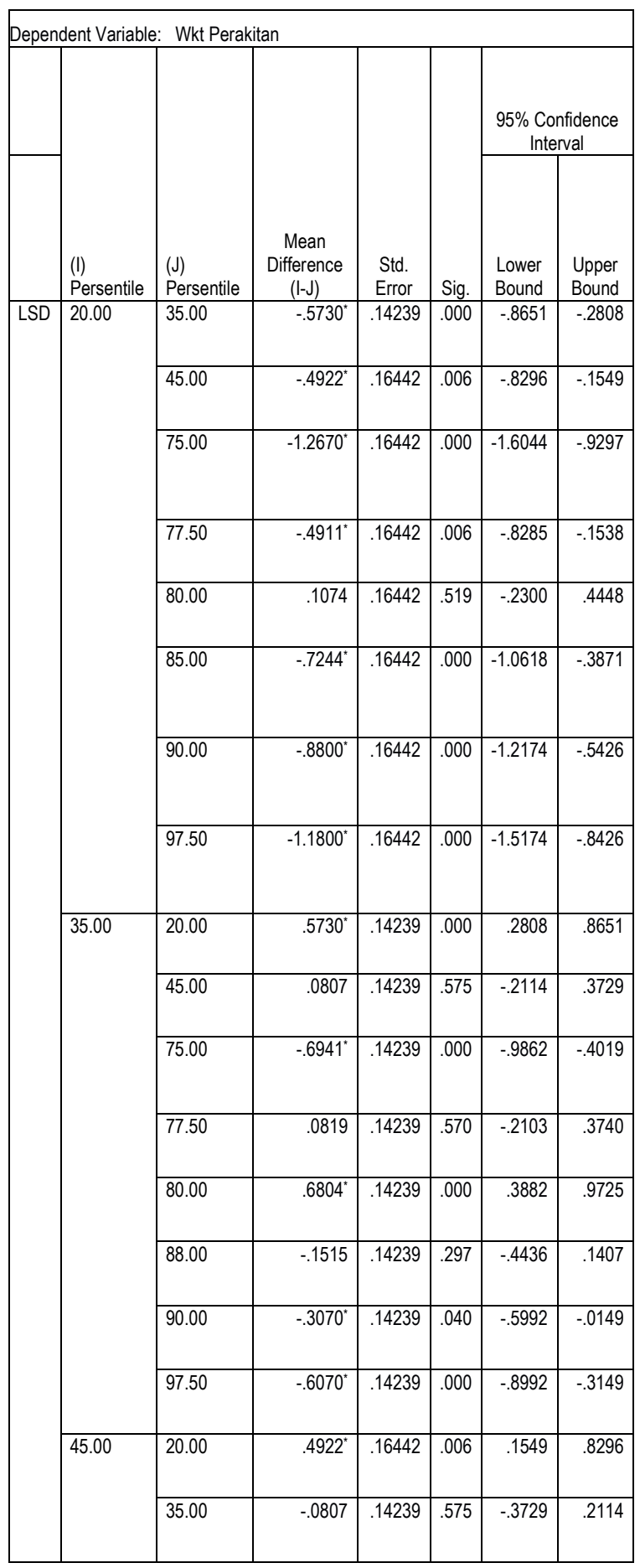

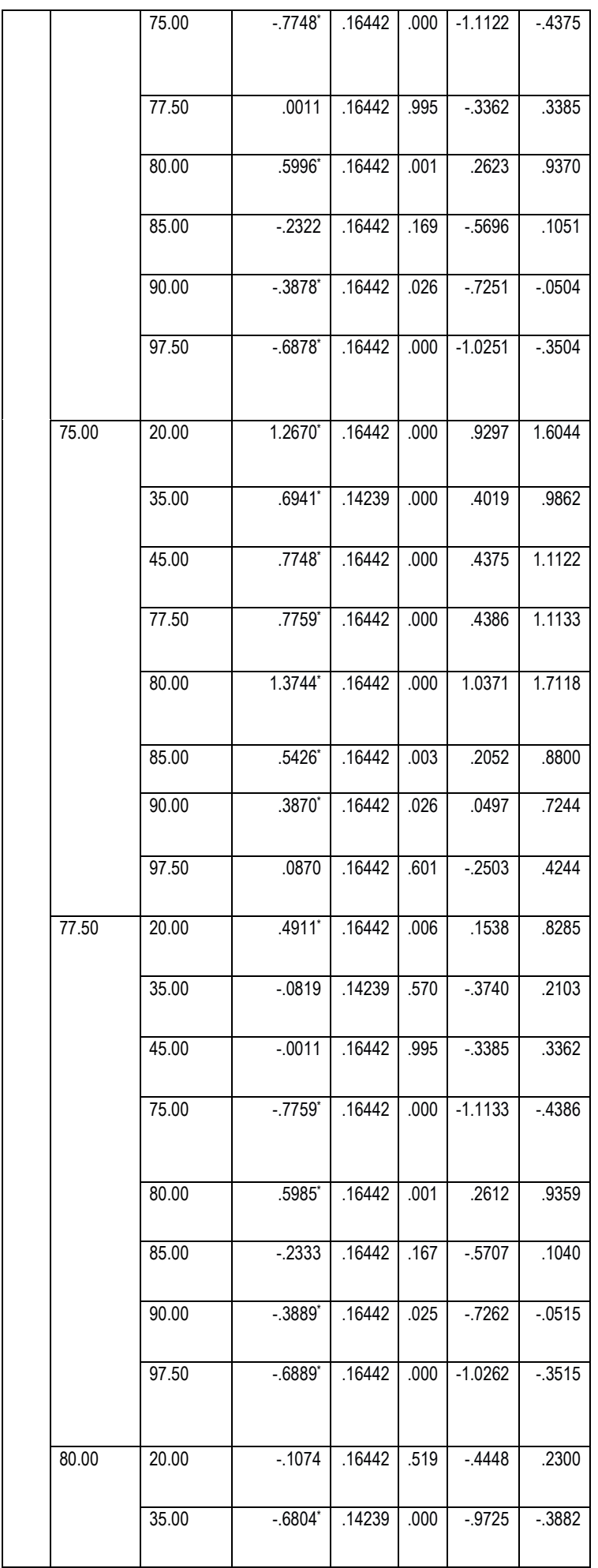




\begin{tabular}{|c|c|c|c|c|c|c|}
\hline & 45.00 & $-.5996^{*}$ & .16442 & .001 & -.9370 & -.2623 \\
\hline & 75.00 & $-1.3744^{*}$ & .16442 & .000 & -1.7118 & -1.0371 \\
\hline & 77.50 & $-.5985^{\circ}$ & .16442 & .001 & -.9359 & -.2612 \\
\hline & 85.00 & $-.8319^{*}$ & .16442 & .000 & \begin{tabular}{|l|}
-1.1692 \\
\end{tabular} & -.4945 \\
\hline & 90.00 & $-.9874^{*}$ & .16442 & .000 & -1.3248 & -6500 \\
\hline & 97.50 & -1.2874 & .16442 & .000 & -1.6248 & -.9500 \\
\hline 85.00 & 20.00 & $.7244^{\circ}$ & .16442 & .000 & .3871 & 1.0618 \\
\hline & 35.00 & .1515 & .14239 & .297 & -.1407 & .4436 \\
\hline & 45.00 & .2322 & .16442 & .169 & -.1051 & .5696 \\
\hline & 75.00 & $-.5426^{*}$ & .16442 & .003 & -8800 & $\begin{array}{l}.2052 \\
\end{array}$ \\
\hline & 77.50 & .2333 & .16442 & .167 & $\begin{array}{l}-1040 \\
\end{array}$ & .5707 \\
\hline & 80.00 & $.8319^{\circ}$ & $\begin{array}{l}.16442 \\
\end{array}$ & .000 & .4945 & 1.1692 \\
\hline & 90.00 & $\begin{array}{l}-.1556 \\
\end{array}$ & .16442 & .352 & -.4929 & .1818 \\
\hline & 97.50 & $-.4556^{*}$ & .16442 & .010 & -.7929 & -.1182 \\
\hline 90.00 & 20.00 & $.8800^{\circ}$ & .16442 & .000 & .5426 & 1.2174 \\
\hline & 35.00 & $.3070^{*}$ & .14239 & .040 & .0149 & .5992 \\
\hline & 45.00 & $.3878^{\prime}$ & $\begin{array}{l}.16442 \\
\end{array}$ & .026 & .0504 & .7251 \\
\hline & 75.00 & $-3870^{*}$ & .16442 & .026 & -.7244 & $\begin{array}{l}.0497 \\
\end{array}$ \\
\hline & 77.50 & $.3889^{\circ}$ & .16442 & .025 & .0515 & .7262 \\
\hline & 80.00 & $.9874^{*}$ & .16442 & .000 & .6500 & 1.3248 \\
\hline & 85.00 & .1556 & .16442 & .352 & -1818 & .4929 \\
\hline & 97.50 & -.3000 & .16442 & .079 & -6374 & .0374 \\
\hline 97.50 & 20.00 & $1.1800^{\circ}$ & .16442 & .000 & .8426 & 1.5174 \\
\hline & 35.00 & $.6070^{*}$ & .14239 & .000 & .3149 & .8992 \\
\hline
\end{tabular}

\begin{tabular}{|l|l|r|r|r|r|c|}
\hline & 45.00 & $.6878^{*}$ & .16442 & .000 & .3504 & 1.0251 \\
\cline { 3 - 8 } & 75.00 & -.0870 & .16442 & .601 & -.4244 & .2503 \\
\cline { 2 - 7 } & 77.50 & $.6889^{*}$ & .16442 & .000 & .3515 & 1.0262 \\
\cline { 2 - 7 } & 80.00 & $1.2874^{*}$ & .16442 & .000 & .9500 & 1.6248 \\
\cline { 2 - 7 } & 85.00 & $.4556^{*}$ & .16442 & .010 & .1182 & .7929 \\
\cline { 2 - 7 } & 90.00 & .3000 & .16442 & .079 & -.0374 & .6374 \\
& & & & & & \\
\hline
\end{tabular}

Tabel 8

Multiple Comparisons

\begin{tabular}{|c|c|c|c|c|c|c|c|}
\hline \multicolumn{2}{|c|}{ Dependent Variable: } & \multicolumn{6}{|c|}{ Wkt Perakitan } \\
\hline & \multirow[b]{2}{*}{$\begin{array}{l}\text { (I) } \\
\text { Lighting }\end{array}$} & \multirow[b]{2}{*}{ (J) Lighting } & \multirow[b]{2}{*}{$\begin{array}{c}\text { Mean } \\
\text { Difference (I-J) }\end{array}$} & \multirow[b]{2}{*}{$\begin{array}{l}\text { Std. } \\
\text { Error }\end{array}$} & \multirow[b]{2}{*}{ Sig. } & \multicolumn{2}{|c|}{$\begin{array}{l}95 \% \text { Confidence } \\
\text { Interval }\end{array}$} \\
\hline & & & & & & $\begin{array}{l}\text { Lower } \\
\text { Bound }\end{array}$ & $\begin{array}{l}\text { Upper } \\
\text { Bound }\end{array}$ \\
\hline \multirow[t]{6}{*}{ LSD } & \multirow[t]{2}{*}{1.00} & 2.00 & $1.1516^{*}$ & .09006 & .000 & 9668 & 1.3363 \\
\hline & & 3.00 & $1.2432^{*}$ & .09006 & .000 & 1.0584 & 1.4280 \\
\hline & \multirow[t]{2}{*}{2.00} & 1.00 & $-1.1516^{*}$ & .09006 & .000 & -1.3363 & -.9668 \\
\hline & & 3.00 & .0917 & .09006 & .318 & -.0931 & .2764 \\
\hline & \multirow[t]{2}{*}{3.00} & 1.00 & $-1.2432^{*}$ & .09006 & .000 & -1.4280 & -1.0584 \\
\hline & & 2.00 & -0917 & .09006 & .318 & -2764 & .0931 \\
\hline \multirow{2}{*}{$\begin{array}{l}\text { Dunnett } \\
\mathrm{t}(2- \\
\text { sided })^{b}\end{array}$} & 1.00 & 3.00 & $1.2432^{*}$ & .09006 & .000 & 1.0331 & 1.4534 \\
\hline & 2.00 & 3.00 & .0917 & .09006 & .499 & -.1185 & .3018 \\
\hline \multicolumn{8}{|c|}{$\begin{array}{l}\text { Based on observed means. } \\
\text { The error term is Mean Square(Error) }=.365 \text {. }\end{array}$} \\
\hline \multicolumn{8}{|c|}{${ }^{*}$. The mean difference is significant at the, 05 level. } \\
\hline \multicolumn{8}{|c|}{ b. Dunnett t-tests treat one group as a control, and compare all other groups against it. } \\
\hline
\end{tabular}




\section{IV.Kesimpulan}

1. Ukuran anthropometri berpengaruh terhadap waktu penyelesaian perakitan otoped.

2. Ukuran anthropometri yang sesuai untuk pekerjaan merakit otoped adalah persentil ke-80

3. Faktor lingkungan fisik kerja seperti temperatur dan kebisisngan tidak mempengaruhi waktu penyelesaian perakitan otoped. Faktor pencahayaan yang mempengaruhi waktu penyelesaian perakitan otoped.

4. Range temperature yang masih nyaman untuk perakitan otoped adalah $20^{\circ} \mathrm{C}-30^{\circ} \mathrm{C}$

5. Range kebisingan yang masih nyaman di telinga pekerja perakitan otoped adalah $50 \mathrm{~dB}-85 \mathrm{~dB}$.

6. Level Pencahayaan yang nyaman untuk mata pekerja perakitan adalah 150 lux.

\section{DAFTAR PUSTAKA}

[1] Sutalaksana, I., Anggawisastra, R., Tjakraatmadja, J, H. (2006). Teknik
Perancangan Sistem Kerja. Bandung: Penerbit ITB Bandung.

[2] Akbari, J., Dehghan, H., Azmoon, H., Forouharmajd, F. (2013). Relationship between Lighting and Noise Levels and Productivity of the Occupants in Automotive Assembly Industry. Journal of Environmental and Public Health Volume 2013.

[3] Vimalanathan, K., Babu, R. B. (2014). The Effect of Indoor Office Enviroment On The Work Performance, Health and Well-being of Office Workers. Journal of Environmental Health Science and Engineering 201412:113.

[4] Seppanen, O., Fisk, J. W., Lei, Q.,(2006). Effect of Temperature On Task Performance In Office Enviroment. Indoor Air Journal 14 (suppl17) pp: 74-81. 